\title{
Architektura mieszkaniowa w Skandynawii - Wybrane przykłady budynków zrównoważonego rozwoju
}

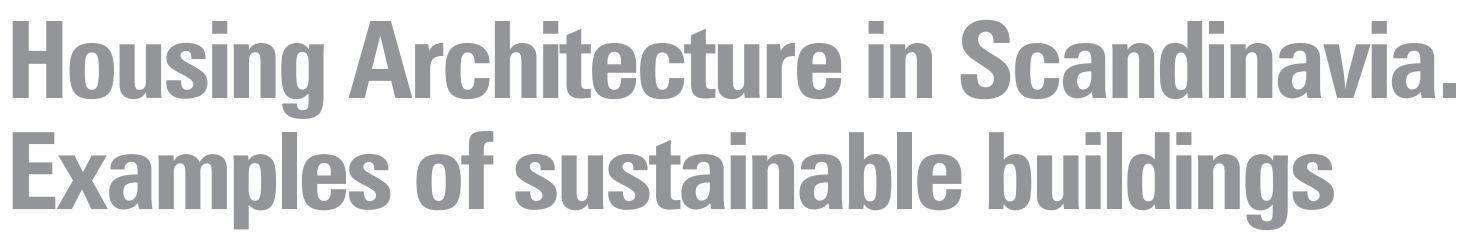

\author{
Streszczenie \\ niem kryteriów do dokonania oceny w kontekście zrównoważonego rozwoju oraz aspektów społecznych. \\ waniem architektury skandynawskiej w kontekście innowacyjności i rozwiązań proekologicznych. \\ Zostały przeanalizowane następujące kompleksy zabudowy mieszkaniowej: \\ Dania: 1. Ellebo Garden Room, 2. Future Sustainable Social Housing, 3. Upcycle House \\ Szwecja: 1. Fittja People's Palace, 2. Greenhouse Augustenborg \\ Finlandia: 1. Puukuokka Housing Block, 2. Siena and Umbra Housing Blocks \\ Norwegia: 1. Plus House Larvik \\ Inicjatywy Nordic Innovation dotyczą zarówno projektów architektonicznych jak i zespołów urbanistycznych. \\ Summary \\ innovation and environment-friendly solutions. \\ The following complexes of housing development were analysed: \\ Denmark: 1. Ellebo Garden Room, 2. Future Sustainable Social Housing, 3. Upcycle House \\ Sweden: 1. Fittja People's Palace, 2. Greenhouse Augustenborg \\ Finland: 1. Puukuokka Housing Block, 2. Siena and Umbra Housing Blocks \\ Norway: 1. Plus House Larvik \\ Nordic Innovations initiatives address both architectural projects and urban planning.
}

Celem niniejszej publikacji jest przedstawienie przykładów architektury mieszkaniowej w krajach skandynawskich z podaInicjatorem konkursu na wyłonienie najlepszych przykładów jest norweska agencja Nordic Innovation zajmująca się propago-

The purpose of this publication is to present examples of residential architecture in Scandinavian countries whilst looking at the criteria for assessment in the context of sustainable development and social aspects. The initiator of the competition for the best examples is the Norwegian Nordic Innovation Agency, which promotes Scandinavian architecture in the context of

Słowa kluczowe: Architektura zrównoważonego rozwoju, kompleks mieszkaniowy, zero emisji dwutlenku węgla, panele słoneczne, elektrownie wiatrowe, interakcja między otoczeniem terenów zielonych a projektowaną architekturą Keywords: Sustainable development architecture, residential complex, zero carbon footprint, solar panels, wind power plants, interaction between green spaces and design architecture

\section{Wstęp}

Spojrzenie z lotu ptaka na Skandynawię pozwala dostrzec rozległe, słabo zaludnione przestrzenie, naturalne krajobrazy, połyskliwe fiordy i skaliste góry, skute lodem jeziora, gęste lasy i zmrożoną tundrę, rozciągające się na północ od położonej na półwyspie Jutlandzkim Danii po krainę Samów na Dalekiej Północy i odległe wyspy Owcze oraz Grenlandię.

Dania, Norwegia, Szwecja i Finlandia to kraje należące do najstarszych europejskich cywilizacji. Mają bogatą wspólną

\section{Introduction}

A bird's-eye view of Scandinavia allows us to see vast, sparsely populated areas, natural landscapes, shimmering fjords and rocky mountains. Ice-covered lakes, dense forests and frozen tundra stretch north from Denmark's Jutland peninsula to the land of the Sami in the far North and the distant Faroe Islands and Greenland.

Denmark, Norway, Sweden and Finland are the countries belonging to the oldest European civilizations. 


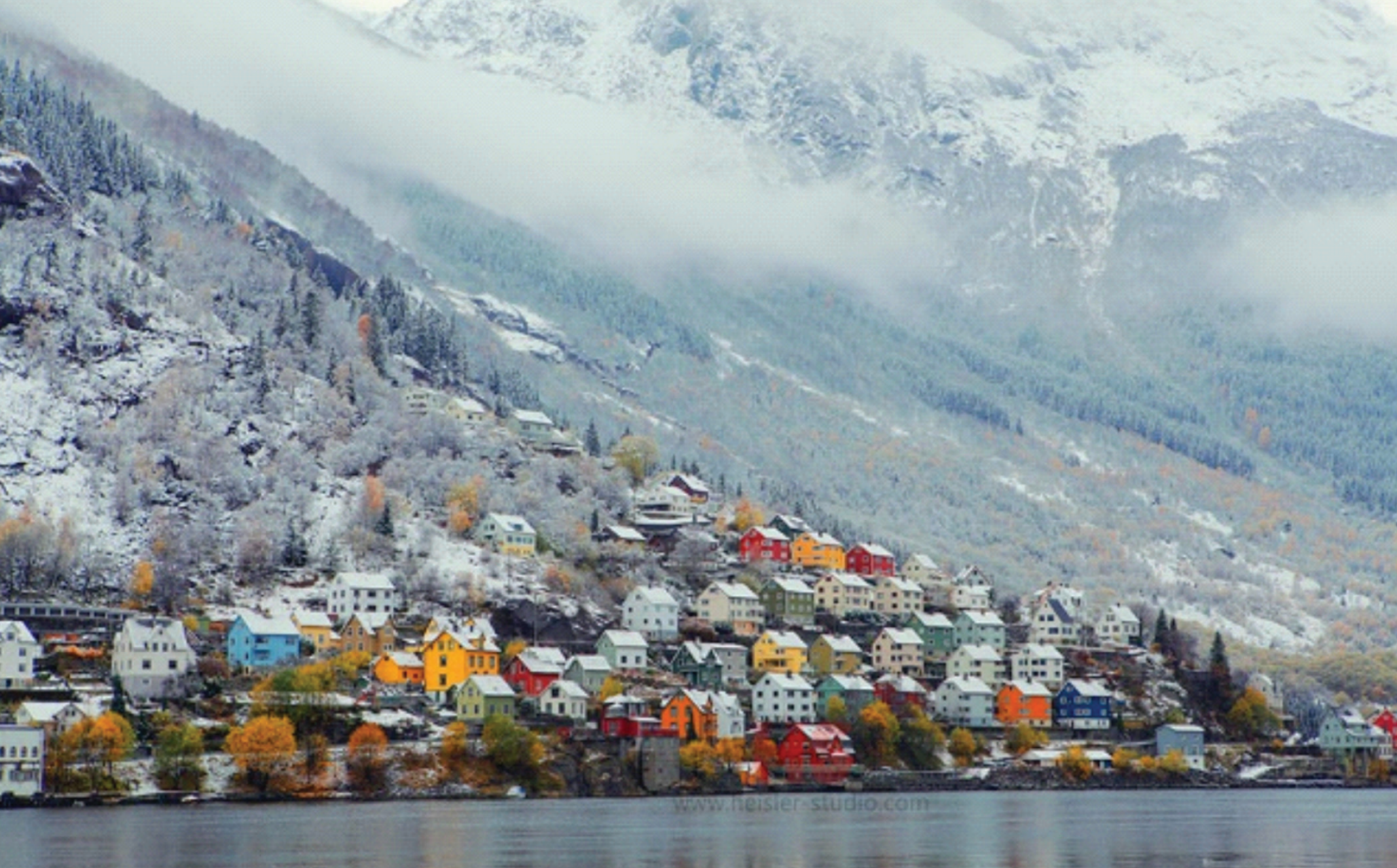

II. 1. Krajobraz skandynawski (Norwegia) / Scandinavian Landscape

tradycję i historię. Skandynawskie stolice: Kopenhaga, Oslo, Sztokholm i Helsinki - to miasta tętniące życiem, o ciekawej architekturze, propagujące nowoczesny design, jak i zdrowy styl życia zgodnie $z$ duchem natury i przyrody.

Celem niniejszej publikacji jest przedstawienie przykładów architektury mieszkaniowej w krajach skandynawskich z podaniem kryteriów do dokonania oceny $w$ kontekście zrównoważonego rozwoju oraz aspektów społecznych. Inicjatorem konkursu na wyłonienie najlepszych przykładów jest norweska agencja Nordic Innovation, zajmująca się propagowaniem architektury skandynawskiej w kontekście innowacyjności i rozwiązań proekologicznych.

\section{Karta kryteriów}

Ustanowiona przez agencję Nordic Innovation została zaakceptowana przez Nordic Council of Ministers. Składa się z 10 zasad - kryteriów dla cceny wybranych przykładów w senza budownictwa zrównoważonego rozwoju a takż wa sen-

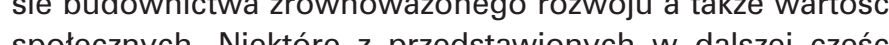

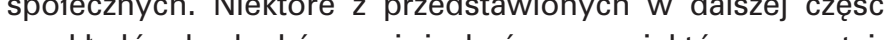
przykladow budykow sa juz ukonzone iekore pozostaja nadal w fazie projektowej.

zostały kryteria, według których dokonano oceny architektonicznych przykładów.

Promowanie wartości humanistycznych $w$ architekturze i dbanie o jakosc zycia.

Promowanie innowacji w rozwiazzaniach architektonicznych jako elementów wiedzy budowlanej.

Łączenie aspektów życia miejskiego z dbałością o środowisko naturalne.

Osiągnięcie zera emisji dwutlenku węgla.

Dbałość o funkcjonalne, inteligentne i estetyczne rozwiązania zgodnie z najlepszą tradycją architektury skandynawskiej. Dbałość o elastyczność, trwałość i ponadczasowość proponowanych przykładów.
They have a rich common history and tradition. The Scandinavian capitals, Copenhagen, Oslo, Stockholm lifestyle in harmony with the spirit of nature.

The purpose of this publication is to present excountries whilst looking at the criteria for assessnovation Agency, which promotes Scandinavia architecture in the context of innovation and environment-friendly solution

2. Criteria Card

The Criteria Card compiled by the Nordic Innovation Agency has been approved by the Nordic criteria for evaluating selected examples in the as considering social values. Some of the exas well presented here are already completed; some are still at the design phase. are listed below. care for the quality of living

(n) architectural solutions as Combining aspects of urban living with care for the environment Demonstrating functional, intelligent and aesthetic Demonstrating flexibli

Dexibility, durability and timelessscape conditions tecture that promotes modern design and a healthy amples of residential architecture in Scandinavian ment in the context of sustainable development for the best examples is the Norwegian Nordic in Council of Ministers. It consists of 10 principles

The criteria for evaluating architectural examples

Promoting humanistic values in architecture and

Achieving zero carbon dioxide emissions solutions in line with the best traditions of ScandiUsing local materials and adapting to local land-

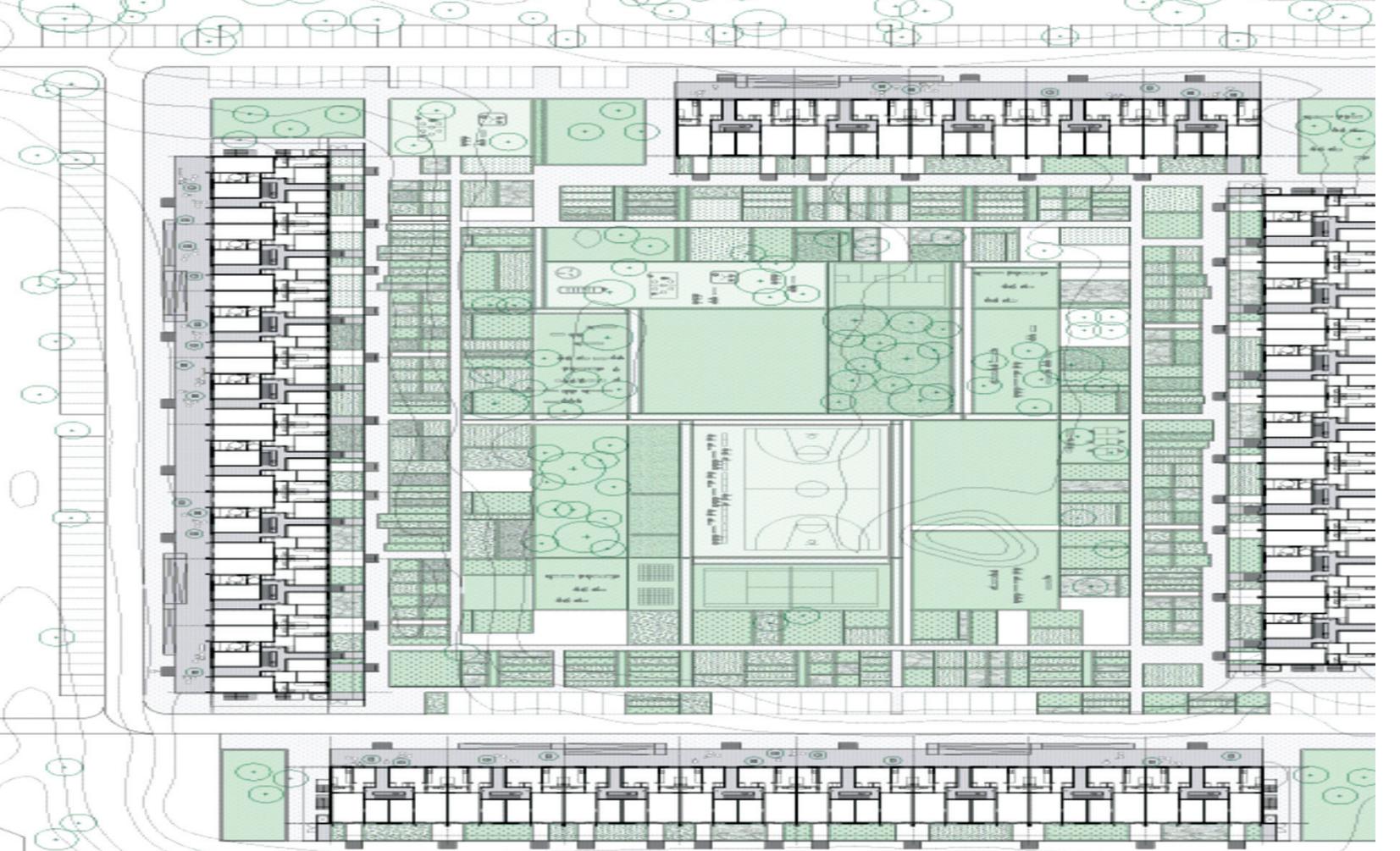

II. 2. Ellebo Garden Room - Rzut parteru / Ellebo Garden Room - Sketch
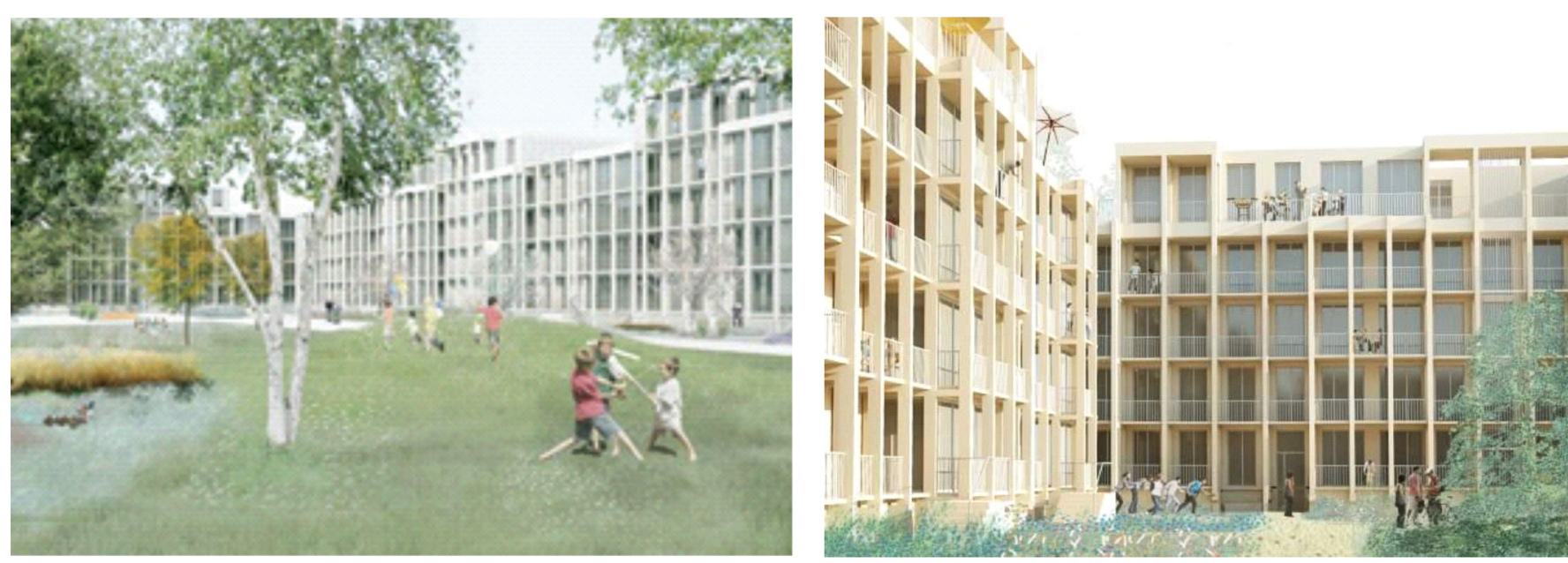

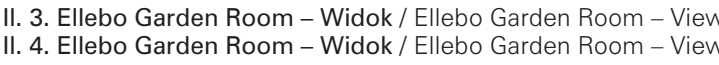

Stosowanie lokalnych surowców i adaptacja do lokalnych warunków krajobrazu

Interdyscyplinarność rozwiązań i współpraca specjalistów ¡ zespołów biorących udział $w$ procesie projektowym Stosowanie rozwiązań ergonometrycznych i skali „ludzkiej" Stosowanie rozwiązań zgodnie z ochroną środowiska Przykładami wyłonionymi w konkursie zorganizowanym przez Nordic Countries Ministers są trzy projekty. 1. Ellebo Gardens Rooms - rewitalizacja osiedla mieszkaniowego z lat 60, położonego w zachodniej części Kopenhagi w Ballerup. 2. Przykład budownictwa socjalnego Future Sustainable Social Housing w Kolding oraz 3. Przykład domu jednorodzinnego "Upcycle House" wykonanego z materiałów po recyclingu. Aby przedstawić ideę rewitalizacji osiedla mieszkaniowego Ellebo, trzeba przede wszystkim pokazac założenia ideowe
Interdisciplinarity in solutions and the cooperation of specialists and teams involved in the design process

Applicale Applying
ronment The examples are three competition projects orEllebo Garden Rooms - a revitalization of the geos housing estame in Balrov, in the wester part of Copenhagen;

The Future Susding; and House", constructed from recycled materis. ganised by the Nordic Countries Ministers: 
